\title{
Karlsruhe's Lochner Moment? A Rational Choice Perspective on the German Federal Constitutional Court's Relationship to the CJEU After the PSPP Decision
}

\author{
Niels Petersen (1D)*
}

(Received 02 July 2020; accepted 07 July 2020)

\begin{abstract}
On May 5, 2020, the German Federal Constitutional Court issued the PSPP decision, sending shock waves through the European Union. This contribution analyzes the consequences of the PSPP decision for the future relationship between the German FCC and the CJEU and for European integration as a whole. The article consists of four parts. First, I will provide some context and model the interaction between domestic and international courts from a rational choice perspective. Second, I will recapitulate some core aspects of the relationship between the German Federal Constitutional Court and the CJEU in particular. I argue that the relationship between both courts had evolved into a strategic equilibrium in which it was costly not to respect the decision of the other party. The third section then looks for reasons why Karlsruhe nevertheless deviated from this equilibrium despite the significant costs involved. The fourth section, finally, considers the way ahead and analyzes what possible consequences for the future relationship between the Federal Constitutional Court and the CJEU.
\end{abstract}

Keywords: PSPP; German Federal Constitutional Court; ECB; pluralism; ultra vires

In 1905, the U.S. Supreme Court struck down a limit for working time hours of bakery employees in a 5-4 decision in Lochner v. New York. ${ }^{1}$ According to the majority, limiting the working hours to 10 hours per day and 60 hours per week violated the freedom of contract, which the Court derived from the due process clause of the 14th amendment. In contemporary legal scholarship, Lochner epitomizes judicial activism. ${ }^{2}$ In the words of Ronald Dworkin, it is often considered the "whipping boy" of U.S. constitutional law. ${ }^{3}$ The significance of Lochner lies not so much in the decision itself, its reasoning or the issue that was decided. Its fundamental importance is rather derived from ushering in the Lochner era, an era characterized by the Supreme Court's economic libertarianism. The Court struck down almost two hundred statutes, many of which introduced progressive labor regulations. ${ }^{4}$

\footnotetext{
${ }^{\star}$ Professor of Law and Co-Director of the Institute for international and comparative public law of the University of Münster. I am very grateful to Matthias Goldmann for valuable comments on an earlier version of the article.

${ }^{1}$ Lochner v. New York, 198 U.S. 45 (1905).

${ }^{2}$ Sujit Choudhry, The Lochner Era and Comparative Constitutionalism, 2 INTERNATIONAL JOURNAL OF CONSTITUTIONAL LAW 1, 2 (2004); Sujit Choudhry, Worse Than Lochner?, in Access to Care, AcCess to Justice: The Legal Debate Over Private Health Insurance in Canada 75, 77 (Colleen M. Flood, Kent Roach \& Lorne Sossin eds., 2005).

${ }^{3}$ Ronald Dworkin, Freedom's Law: The Moral Reading of the American Constitution 82 (1996).

${ }^{4}$ Choudhry, The Lochner Era and Comparative Constitutionalism, supra note 2, at 4-5.
} 
However, Lochner is not only a symbol for judicial activism, but also for the political resistance that such activism can provoke. The Lochner era came to an end in the late 1930s after the Court had repeatedly struck down parts of Franklin D. Roosevelt's "New Deal" legislation. ${ }^{5}$ Seeing his major political project endangered by the Court, Roosevelt proposed a so-called court-packing plan. According to this plan, the President had the right to appoint up to six new members to the Supreme Court, one for each Justice over the age of 70. The court-packing plan ultimately failed, but it had its intended effect. In 1937, the Supreme Court finally gave up its resistance to the "New Deal" and turned away from the economic libertarianism of the Lochner era.

When the German Federal Constitutional Court handed down its PSPP decision in early May of this year, it characterized a break with the past whose significance cannot be overestimated. ${ }^{6}$ Certainly, Karlsruhe had often criticized the CJEU before and developed doctrinal exceptions to the supremacy of EU law. ${ }^{7}$ However, it had always used this criticism to create leverage and to influence the Court of Justice's jurisprudence. ${ }^{8}$ The PSPP decision is the first instance in which the Federal Constitutional Court openly defied the Court of Justice.

In this contribution, I argue that the Lochner episode provides important lessons for assessing the PSPP judgment and its aftermath. In issuing the decision, the Court might have overplayed its hand. The argument proceeds in four steps. First, I will provide some context and model the interaction between domestic and international courts from a rational choice perspective, assuming strategic judicial decision-making (A.). Second, I will recapitulate some core aspects of the relationship between the German Federal Constitutional Court and the CJEU in particular. I argue that the relationship between both courts had evolved into a strategic equilibrium in which it was costly not to respect the decision of the other party (B.). The third section then looks for reasons why Karlsruhe nevertheless deviated from this equilibrium despite the significant costs involved (C.). The fourth section, finally, considers the way ahead and analyzes what lessons the Lochner episode may teach us for the future relationship between the Federal Constitutional Court and the CJEU (D.).

\section{A. Judicial Pluralism and Strategic Decision-Making of Courts}

When modelling the relationship between domestic and international courts, the pluralist model has for quite some time been the most prominent approach in international and comparative legal scholarship. ${ }^{9}$ The main characteristic of the pluralist model is that ultimate judicial authority is

\footnotetext{
${ }^{5}$ On the extent of the Court's resistance, see Richard H. Pildes, Is the Supreme Court a "majoritarian" Institution?, 2010 THE Supreme Court Review 103, 129-30 (2010).

${ }^{6}$ Bundesverfassungsgericht [BVerfG], Cases Nos. 2 BvR 859/15 et al., 5 May 2020, English translation available under http:// www.bverfg.de/e/rs20200505_2bvr085915en.html [hereinafter PSPP II].

${ }^{7}$ See Niels Petersen, Germany, in Duelling for Supremacy: International Law vs. National Fundamental Principles: A Comparative Law Perspective 89, 90-96 (Fulvio Maria Palombino ed., 2019).

${ }^{8} I d$. at 96.

${ }^{9}$ See, e.g., Nico Krisch, Beyond Constitutionalism: The Pluralist Structure of Postnational Law (2010); Andreas Paulus, The Emergence of the International Community and the Divide Between International and Domestic Law, in New Perspectives on the Divide Between National and International Law 216 (Janne E. Nijman \& André Nollkaemper eds., 2007); Niels Petersen, The Concept of Legal and Constitutional Pluralism, in InTERnATIONAL TAX LAW: New Challenges to and From Constitutional and Legal Pluralism 1 (Joachim Englisch ed., 2016); Paul Schiff Berman, Global Legal Pluralism: A Jurisprudence of Law Beyond Borders (2012); Nico Krisch, The Open Architecture of European Human Rights Law, 71 MODERN LAw REVIEw 183 (2008); Mattias Kumm, The Jurisprudence of Constitutional Conflict: Constitutional Supremacy in Europe Before and After the Constitutional Treaty, 11 EUROPEAN Law Journal 262 (2005); Michel Rosenfeld, Rethinking Constitutional Ordering in an Era of Legal and Ideological Pluralism, 6 International Journal of Constitutional Law 415 (2008); Alec Stone Sweet, A Cosmopolitan Legal Order: Constitutional Pluralism and Rights Adjudication in Europe, 1 Global Constitutionalism 53 (2012); Alec Stone Sweet, The Structure of Constitutional Pluralism, 11 InTERnational Journal of Constitutional LAW 491 (2013); Armin von Bogdandy, Pluralism, Direct Effect, and the Ultimate Say: On the Relationship Between International and Domestic Constitutional Law, 6 International Journal of Constitutional LaW 397 (2008); Armin von Bogdandy \&
} 
undefined. ${ }^{10}$ There is no clear hierarchy between the domestic and the international level. Instead, we observe an equilibrium where both the international and the domestic court claim ultimate authority, while still respecting and reacting to the authority of the other court.

In such a setting the domestic court would, in principle, accept the supremacy of the international level. At the same time, it reserves itself the right to exercise ultimate authority under certain circumstances. The principal example of this strategy is the so-called Solange reservation. ${ }^{11}$ According to the Solange reservation, a court does not review acts of an international or supranational organization if individual rights are protected adequately in this organization. The Court imposing the reservation thus claims ultimate authority, but refrains from exercising it if certain conditions are fulfilled.

Meanwhile, the international court also pays respect to the national courts. While it claims the ultimate authority and asserts supremacy of international over domestic law, it takes into account concerns of domestic courts and grants the latter a certain autonomy in their decision-making. The doctrinal instrument of choice could, for example, be a margin of appreciation doctrine. ${ }^{12}$ Depending on the procedural situation, courts could also just give abstract guidance and refrain from deciding the concrete case-a strategy that is often pursued by the Court of Justice in preliminary reference procedures. Furthermore, international courts may adjust their case law if there is significant pressure from domestic courts. ${ }^{13}$

Pluralist patterns emerge if both the domestic and the international court are interdependent on each other. International courts are usually dependent on domestic courts because they cannot implement their own decisions. At the same time, domestic apex courts are not entirely independent institutions that they are often perceived to be. Instead, they have to rely on other institutions to implement their decisions. Furthermore, there is always the danger that the legislature curtails the independence of an apex court. The most prominent example is Roosevelt's court-packing plan. But also the Adenauer government had plans to restrict the influence of the German Constitutional Court. ${ }^{14}$ Furthermore, the recent developments in Hungary and Poland are vivid illustrations of the vulnerability of courts' competences. ${ }^{15}$ This does not mean that apex courts are

Stephan Schill, Overcoming Absolute Primacy: Respect for National Identity Under the Lisbon Treaty, 48 COMMON MARKET LaW Review 1417 (2011); Ana Bobic, Constitutional Pluralism Is Not Dead: An Analysis of Interactions between Constitutional Courts of Member States and the European Court of Justice, 18 GERMAN L.J. 1395 (2017). See also Franz C. Mayer, Multilevel Constitutional Jurisdiction, in Principles of European CONSTITUTIONAL LAW 399 (Armin von Bogdandy \& Jürgen Bast eds., $2^{\text {nd }}$ ed. 2010) (observing or advocating cooperative relationships between courts); HEIKO Sauer, Jurisdiktionskonflikte in Mehrebenensystemen (2008); Matthias Klatt, Die Praktische Konkordanz

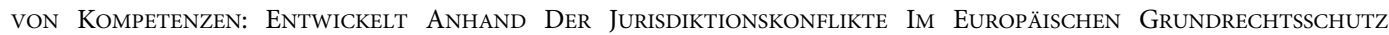
(2014) (proposing to conceptualize jurisdictional conflicts by using formal principles, which do not establish abstract hierarchies, but resolve them on a case-by-case basis); Lech Garlicki, Cooperation of Courts: The Role of Supranational Jurisdictions in Europe, 6 InTERnATIONAL Journal OF CONSTITUTIONAL LAW 509 (2006).

${ }^{10}$ Mattias Kumm, Who is the Final Arbiter of Constitutionality in Europe: Three Conceptions of the Relationship Between the German Federal Constitutional Court and the European Court of Justice, 36 COMMON MKT. L. REV. 351,384 (1999).

${ }^{11}$ Bundesverfassungsgericht [BVerfG] [Federal Constitutional Court] Oct. 22, 1986, 73 ENTSCHEIDUNGEN DES BundesVERFASSUNGSGERICHTS [BVERFGE] 339, 378 [hereinafter Solange II].

${ }^{12}$ Handyside v. UK, 24 EUR. CT. H.R. (ser. A) 48 (1976).

${ }^{13}$ An example is the development of a fundamental rights jurisprudence by the ECJ, see UlRICH HALTERN, EUROPARECHT: Dogmatik im KonteXt, Vol. II: Rule of LaW, Verbunddogmatik, Grundrechte 1403 (3 ${ }^{\text {rd }}$ ed. 2017).

${ }^{14}$ See Richard HÄUßLER, DER KONFLIKT ZWISCHEN BUNDESVERFASSUNGSGERICHT UND POLITISCHER FÜHRUNG 40-47 (1994) (giving a detailed account of the reform plans of the Adenauer government); HEINZ LAUFER, VERFASSUNGSGERICHTSBARKEIT UND POlitischer Prozeß 169-206 (1968). See also Manfred Baldus, Frühe Machtkämpfe - Ein Versuch über die historischen Gründe der Autorität des Bundesverfassungsgerichts, in DAS LÜTH-URTEIL AUS (RECHTS-)HISTORISCHER SICHT 237, 241-42 (Thomas Henne and Arne Riedlinger eds, 2005); Oliver W. Lembcke, Das Bundesverfassungsgericht und die Regierung Adenauer - vom Streit um den Status zur Anerkennung der Autorität, in Das BUNDESVERFASSUNGSGERICHT IM POLITISCHEN System 151, 156-57 (Robert Christian van Ooyen and Martin H.W. Möllers eds., 2006).

${ }^{15}$ See Wojciech Sadurski, Poland's Constitutional Breakdown (2019); Kim Lange Scheppele, Understanding Hungary's Constitutional Revolution, in CONSTITUTIONAL CRISIS IN THE EUROPEAN Constitutional Area 124 (Armin von Bogdandy \& Pál Sonnevend eds., 2015). 
totally dependent on the executive and the legislature. However, they need to find support if they want to challenge the latter. The most important power resource of courts is their legitimacy, that is, their acceptance by public opinion. ${ }^{16}$ If courts enjoy strong legitimacy, curtailing their powers will be costly for the legislative majority. It could be seen as an attack on the rules of the democratic game and lead to a loss in public support for the ruling party or coalition.

For domestic courts, dependence on international courts may, therefore, stem from a strong commitment to international cooperation, both by the political elites and the general public. If political elites and public opinion are rather critical to international cooperation, courts will usually not be very open to the implementation of judgments of international courts. An example is the case law of the U.S. Supreme Court. The Supreme Court denied judgments of the International Court of Justice a direct effect within domestic U.S. law. ${ }^{17}$ However, the judicial calculus changes when a country shows a strong commitment towards supranational integration or international cooperation. If a court, in these circumstances, defies international or supranational courts and rejects the implementation of their judgments, it might face a backlash from the political branches. ${ }^{18}$ If there is strong support for international integration in public opinion, domestic courts may lose legitimacy if they refuse to comply with decisions of international courts. Consequently, domestic courts are dependent on a cooperative relationship with an international court to the extent there is a strong political commitment towards international cooperation or integration.

\section{B. The Relationship between the German Federal Constitutional Court and the CJEU Before the PSPP Decision}

Before the PSPP decision, the relationship between the Federal Constitutional Court and the CJEU was a textbook example of judicial pluralism. Both courts claimed ultimate authority. At the same time, they also expressed respect for and refrained from openly defying the other court. The German Federal Constitutional Court has developed several doctrinal instruments to maintain ultimate authority, while generally accepting the supremacy of EU law (I.). Similarly, the Court of Justice has fiercely defended the absolute supremacy of EU law, but also developed strategies to take the concerns of Karlsruhe and other domestic courts into account (II.). This equilibrium emerged because there was a strong interdependence between both courts (III.).

\section{The Exceptions Developed by the German Federal Constitutional Court}

The case law of the German Federal Constitutional Court regarding European integration is well known, so I will limit myself to a very brief sketch. ${ }^{19}$ Karlsruhe has generally accepted the supremacy of EU law. However, it has developed three exceptions for situations in which the

\footnotetext{
${ }^{16}$ Andrej Lang, Wider die Metapher vom letzten Wort: Verfassungsgerichte als Wegweiser, in DAS LETZTE WORT: Rechtssetzung und Rechtskontrolle in Der Demokratie 15, 27 (Dominik Elser et al. eds., 2014); GeORG VANBerG, The Politics of Constitutional Review in Germany 49-53 (2005); Christoph Engel, Delineating the Proper Scope of Government: A Proper Task for a Constitutional Court?, 157 Journal of Institutional AND TheORETICAL ECONOMICS 187, 213 (2001); Clifford James Carrubba, A Model of the Endogenous Development of Judicial Institutions in Federal and International Systems, 71 Journal of Politics 55, 65 (2009); Walter F. Murphy \& Joseph Tanenhaus, Publicity, Public Opinion, and the Court, 84 Northwestern University LaW Review 985 (1990); Lee Epstein, Jack Knight \& Olga Shvetsova, The Role of Constitutional Courts in the Establishment and Maintenance of Democratic Systems of Government, 35 LAW \& SOCIETY REVIEW 117, 125 (2001).

${ }^{17}$ See Sanchez-Llamas v. Oregon, 548 US 331 (2006); Medellín v. Texas, 128 S. Ct. 1346 (2008).

${ }^{18}$ Certainly, political support for different instances of international cooperation may vary. What is decisive for a court's strategic calculus is not diffuse support for international cooperation in general, but specific support for a specific international or supranational organization and the extent to which the success of the latter depends on the acceptance of the decisions of its judicial body.

${ }^{19}$ For a more detailed account, see Petersen, supra note 7 , at 90-96.
} 
Court reserves itself ultimate authority. The first and most prominent exception is the so-called Solange reservation, according to which the Court refrains from reviewing EU legal acts on their conformity with German fundamental rights to the extent that there is a sufficient level of fundamental rights protection on the EU level. ${ }^{20}$ However, the Solange reservation has lost its practical relevance. The latest confirmation is a decision from November 2019 in which the German Federal Constitutional Court has started to review acts of German institutions determined by EU law on their consistency with EU fundamental rights. ${ }^{21}$

Second, the Court has developed a constitutional identity review to preserve the normative core of the German constitution. ${ }^{22}$ This concerns, in particular, the principle of democracy, as understood by the Federal Constitutional Court, the rule of law, ${ }^{23}$ and the guarantee of human dignity. ${ }^{24}$ Third and most controversially, the Court has established an ultra vires review, to which it resorted in the PSPP decision. ${ }^{25}$ Under the ultra vires review, it reserves itself the right-after a preliminary reference to the Court of Justice-to review whether EU institutions have acted within the competences that were accorded to them by the EU treaties.

Before, the PSPP decision, the Federal Constitutional Court had never provoked an open conflict with the Court of Justice. While it had exploited grey areas and sometimes successfully nudged the Court of Justice in specific directions, it had not refused to comply with the latter's judgments. It had never found an EU legal act to violate German fundamental rights nor German constitutional identity; and while sometimes voicing criticism, it had also never held that an EU legal act had been enacted ultra vires.

\section{The Appeasement Strategy of the Court of Justice}

The Court of Justice has also claimed ultimate authority. It developed the doctrine of absolute supremacy of EU law over domestic law ${ }^{26}$ and even domestic constitutions. ${ }^{27}$ At the same time,

\footnotetext{
${ }^{20}$ Solange II, at 378 .

${ }^{21}$ See Bundesverfassungsgericht [BVerfG], Case No. 1 BvR 276/17, 6 November 2019, at paras. 53-67 [hereinafter: Right to be forgotten II]. Nevertheless, the Constitutional Court has refrained from formally disavowing the Solange reservation, see id., at paras. $47-48$.

${ }^{22}$ Bundesverfassungsgericht [BVerfG] [Federal Constitutional Court] Mar. 31, 1998, 89 ENTSCHEIDUNGEN DES BundesVERFASSUNGSGERICHTS [BVERFGE] 155, 172 [hereinafter Maastricht]; Bundesverfassungsgericht [BVerfG] [Federal Constitutional Court] June 30, 2009, Entscheidungen des Bundesverfassungsgerichts [BVerfGE] 123, 267, 344, 353-354, 359-363 [hereinafter Lisbon Judgement]; Bundesverfassungsgericht [BVerfG] [Federal Constitutional Court] Dec. 15, 2015, Entscheidungen DEs Bundesverfassungsgerichts [BVERFGE] 140, 317 [hereinafter European Arrest Warrant II]. On the constitutional identity review, see Daniel Thym, Rückzug oder Offensive? Die Identitätskontrolle von EU-Recht durch das BVerfG, in Verwaltung, Verfassung, Kirche: Konstanzer Symposium aus Anlass Des 80. Geburtstags von Hartmut Maurer (Martin Ibler ed., 2012).

${ }^{23}$ Lisbon Judgement, at 344, 353-354, 359-363.

${ }^{24}$ European Arrest Warrant II, at 317.

${ }^{25}$ Bundesverfassungsgericht [BVerfG] [Federal Constitutional Court] July 6, 2010, 126 ENTSCHEIDUNGEN DES Bundesverfassungsgerichts [BVerfGE] 286 [hereinafter Honeywell]; Maastricht at 188; Lisbon Judgement at 353-355. On the ultra vires review, see Christian Calliess, Die Europarechtliche Ultra-Vires-Kontrolle des Bundesverfassungsgerichts: Stumpfes Schwert oder Gefahr für die Autorität des Unionsrechts?, in HERAUSFORDERUNGEN AN STAAT UND VERFASSUNG: Liber Amicorum für Torsten Stein zum 70. Geburtstag 446 (Christian Calliess ed., 2015); Peter Michael Huber, Die Ultra-Vires-Rüge, in Grundgesetz und Europa: Liber Amicorum für Herbert Landau zum Ausscheiden aus dem Bundesverfassungsgericht 233 (Volker Bouffier et al. eds., 2016); Markus Ludwigs, Der Ultra-Vires-Vorbehalt des BVerfG: Judikative Kompetenzanmaßung oder legitimes Korrektiv?, 34 NeUE ZEITSCHRIFT FÜR VERWALTUNGSRECHT 537 (2015); Martin Nettesheim, Kompetenzdenken als Legitimationsdenken: Zur Ultra-Vires-Kontrolle Im rechtspluralistischen Umfeld, 69 JuRISTENZEITUNG 585 (2014); Karsten Schneider, Der Ultra-Vires-Maßstab Im Außenverfassungsrecht: Skizze sicherer Vollzugszeitumgebungen für zwischenstaatliche und supranationale Integrationsprozesse, 139 ARCHIV DES ÖFFENTLICHEN Rechts 196 (2014); Mattias Wendel, Kompetenzrechtliche Grenzgänge: Karlsruhes Ultra-Vires-Vorlage an den EuGH, 74 ZEITSCHRIFT FÜR AUSLÄNDISCHES ÖFFENTLICHES RECHT UND VÖLKERRECHT 615 (2014).

${ }^{26}$ Case 6/64, Costa v. E.N.E.L., 1964 E.C.R. 585 (1964).

${ }^{27}$ Case $11 / 70$, Internationale Handelsgesellschaft, 1970 E.C.R. 1125, para. 4 (1970).
} 
it also showed significant restraint towards domestic courts and took their interests seriously. This is probably demonstrated most clearly in instances in which the Court of Justice adjusted its jurisprudence in order to alleviate concerns of member states courts. Most famously, it developed a fundamental rights jurisprudence after $1969,{ }^{28}$ even though it had, for a long time, resisted such a move. However, when it received signals from member state courts that they might start to review EC legal acts on their conformity with domestic fundamental rights, ${ }^{29}$ it changed course. It derived fundamental rights from general principles of EC law despite the lack of a codified fundamental rights catalogue. ${ }^{30}$ Similarly, the Court of Justice followed the German Federal Constitutional Court in the interpretation of the Framework Decision on the European arrest warrant. When the latter ruled that a conviction in absentia without the accused being aware of the criminal procedure against him violated the German guarantee of human dignity and interpreted the Framework Decision in conformity with its understanding of human dignity, ${ }^{31}$ the Court of Justice accepted this interpretation. ${ }^{32}$ Karlsruhe had not initiated a preliminary reference procedure before the Court of Justice, ${ }^{33}$ even though the latter had previously considered a conviction in absentia not necessarily to be an exception to automatic extradition under the European Arrest Warrant. ${ }^{34}$

Another prominent example is the recent Taricco saga. ${ }^{35}$ The cases concerned limitation clauses for VAT fraud in Italian criminal law. After the limitation period had been shortened by the Italian legislature, an Italian tribunal referred a question on the validity of these limitation clauses to the Court of Justice. In Taricco, the CJEU held that limitation clauses which were too short to allow an effective prosecution of VAT fraud violated Art. 325 TFEU. ${ }^{36}$ Furthermore, the Court argued that a retroactive disapplication of limitation clauses did not violate the prohibition of retroactive criminal sanctions in Art. 49 (1) EUChFR. ${ }^{37}$ When the case came to the Italian Constitutional Court, the latter initiated a second preliminary reference procedure. ${ }^{38}$ According to the longstanding interpretation of the Italian Constitutional Court, the limitation clauses formed part of substantive criminal law. Therefore, they were subject to the prohibition of retroactive application of criminal sanctions. ${ }^{39}$ Consequently, the court asked the CJEU to reconsider its interpretation of Art. 49 (1) EUChFR, arguing that a retroactive disapplication of the limitation clause would violate the principle of sufficient precision of criminal norms. ${ }^{40}$ The Court of Justice accepted this reasoning and held that the Italian courts should refrain from disapplying the limitation clauses if they found that such a disapplication would be in conflict with the principles foreseeability, precision and non-retroactivity. ${ }^{41}$

\footnotetext{
${ }^{28}$ Case 29/69, Stauder, 1969 E.C.R. 419 (1969); Internationale Handelsgesellschaft, Case 11/70, at 1125.

${ }^{29}$ Bundesverfassungsgericht [BVerfG] [Federal Constitutional Court] May 29, 1974, 37 ENTSCHEIDUNGEN DES Bundesverfassungsgerichts [BVerfGE] 271, 285 [hereinafter Solange I]; Corte costituzionale, 27 Dec. 1973, Frontini, 14 CMLR 372 (1974).

${ }^{30}$ HaLtern, supra note 12 , at para. 1403.

${ }^{31}$ European Arrest Warrant II, at 342-352.

${ }^{32}$ ECJ, Joint Cases C-404/15 \& C-659/15, Căldăraru v. Generalstaatsanwaltschaft Bremen, ECLI:EU:C:2016:198, Judgement of Apr. 3, 2016.

${ }^{33}$ The court discussed this possibility but came to the result that a preliminary reference was not necessary because EU law was clear on this issue, see European Arrest Warrant II, at 356-366.

${ }^{34}$ ECJ, Case C-399/11, Melloni v. Ministerio Fiscal, ECLI:EU:C:2013:107, Judgement of Feb. 26, 2013.

${ }^{35}$ For a concise account, see Matteo Bonelli, The Taricco saga and the consolidation of judicial dialogue in the European Union, 25 MaAstricht Journal of EUROPEAN ANd Comparative LaW 357 (2018).

${ }^{36}$ Case C-105/14, Criminal Proceedings against Ivo Taricco and Others, ECLI:EU:C:2015:555, Judgment of Sept. 8, 2015, at paras. $35-48$.

${ }^{37} \mathrm{Id}$., at para. 55 .

${ }^{38}$ Italian Constitutional Court, Order no. 24/2017.

${ }^{39} I d$.

${ }^{40} \mathrm{Id}$.

${ }^{41}$ Case C-42/17, M.A.S., M.B., ECLI:EU:C:2017:936, Judgment of Dec. 5, 2017, at paras. 58-62.
} 
Sometimes, the Court has also made smaller adjustments to specific doctrines in order to respect sensibilities of members states' courts. One example is the case law on the protection of fundamental rights as a legitimate interest to restrict fundamental freedoms. When the Court of Justice developed the doctrine in Schmidberger, it relied on EU fundamental rights. ${ }^{42}$ One year later, when the German Federal Administrative Court referred a case to the CJEU concerning the relationship between the EU fundamental freedoms and human dignity in Omega, the latter had to adjust. ${ }^{43}$ On the one hand, the Court of Justice was aware of the fundamental importance that the guarantee of dignity played in the German legal order and did not want to provoke a potential conflict with the German federal courts over this matter. On the other hand, it did not want to endorse the highly debatable concept of dignity that the Federal Administrative Court had adopted as reference for the EU legal order. Consequently, it relied on the domestic principle of human dignity. ${ }^{44}$ It argued that it was "compatible with Community law," and held that it could serve as a legitimate interest for restricting the EU fundamental freedoms. ${ }^{45}$

While less noticeable, an arguably even more important element of the strategy of the CJEU is the flexibility that the Court has granted to member states' courts. ${ }^{46}$ Even though the Court of Justice has not explicitly adopted the margin of appreciation doctrine that characterizes the case of law of the European Court of Human Rights in Strasburg, it has found other means to respect the decision-making power of national courts. In the preliminary reference procedure, it often only gives abstract guidance and leaves it to national courts to apply this guidance to the concrete case, thereby granting the latter significant discretion. Just to give one example, in Akerberg Fransson, the Court of Justice held that EU fundamental rights were applicable in the tax fraud case of a Swedish fisher. ${ }^{47}$ But it left the determination of whether the Swedish authorities had violated the guarantee of ne bis in idem in the concrete case to the Swedish court which had initiated the preliminary reference procedure.

Certainly, the overview provided in this section is far from comprehensive. Nevertheless, it illustrates how the CJEU gives domestic courts flexibility and respects their interests, while insisting on the doctrine of absolute supremacy of EU law that is at the heart of its claim for ultimate judicial authority.

\section{The Interdependency Between Both Courts}

The brief analysis of the interaction between the German Federal Constitutional Court and the CJEU, prior to PSPP, illustrate the mutually beneficial relationship that had emerged between both courts. Karlsruhe used the doctrinal exceptions it had developed to nudge the Court of Justice into a particular direction and was often successful in influencing the Luxemburg case law. The CJEU, for its part, showed respect for the concerns of the Federal Constitutional Court by implicitly adjusting its jurisprudence. At the same time, it maintained its claim of supremacy of EU law and could largely rely on the implementation of its judgments by the German Federal Constitutional Court. ${ }^{48}$

\footnotetext{
${ }^{42}$ Case C-112/00, Eugen Schmidberger, Internationale Transporte und Planzüge v. Republik Österreich, 2003 E.C.R. I-5694, at paras. 70-80 [hereinafter Schmidberger] (2003).

${ }^{43}$ Case C-36/02, Omega Spielhallen- und Automatenaufstellungs-GmbH v. Oberbürgermeisterin der Bundesstadt Bonn, 2004 E.C.R. I-9641.

${ }^{44} I d$., at para. 32 ("fundamental value enshrined in the national constitution").

${ }^{45} I$., at paras. $34-35$.

${ }^{46}$ See Matthias Goldmann, Constitutional Pluralism as Mutually Assured Discretion: The Court of Justice, the German Federal Constitutional Court, and the ECB, 23 MAASTricht Journal of European AND Comparative LAW 119 (2016) (highlighting the strategy of mutually assured discretion).

${ }^{47}$ ECJ, Case C-617/10, Åklagaren v. Åkerberg Fransson, ECLI:EU:C:2013:105, Judgement of Feb. 26, 2013.

${ }^{48}$ This is underlined in particular by the fact that the Federal Constitutional Court considers the refusal of a preliminary reference to the Court of Justice a violation of Art. 101 (1) of the Constitution, see Bundesverfassungsgericht [BVerfG] [Federal Constitutional Court] May 31, 1990, 82 EntsCheidungen des Bundesverfassungsgerichts [BVerfGE] 159, 195-96; Bundesverfassungsgericht [BVerfG] [Federal Constitutional Court] May 31, 1990, 135 ENTSCHEIDUNGEN DES
} 
This equilibrium emerged because of the interdependency of both courts. ${ }^{49}$ On the one hand, the CJEU could not alienate Karlsruhe because it was dependent on the latter for the implementation of its judgments in the German legal order. ${ }^{50}$ On the other hand, the German Federal Constitutional Court was prudent not to endanger the project of European integration. Germany's membership in the EU enjoys broad political support across the political spectrum. The challenges to European integration that led to landmark cases, such as the Maastricht, ${ }^{51}$ the Lisbon ${ }^{52}$ or the recent PSPP decisions ${ }^{53}$, all came from the fringes of the political spectrum. Consequently, if Karlsruhe had seriously hampered European integration, it may have faced a significant political backlash.

\section{Why Did Karlsruhe Do It?}

If the relationship between the Federal Constitutional Court and the Court of Justice indeed presents itself as an equilibrium as I argued above, then an obvious question imposes itself: Why did the Court defy the CJEU in its PSPP decision? While the Constitutional Court had obvious success in influencing the CJEU using the Solange or the constitutional identity reservations, the ultra vires review differs from the former two with regard to the strategic setting. There is a decisive procedural difference that puts the Constitutional Court in a weaker position when initiating a preliminary reference procedure. National courts usually employ constitutional identity arguments in grey areas where it is not clear that the insistence on national constitutional identity would come into conflict with EU Law. ${ }^{54}$ If the Federal Constitutional Court-in such a situation-declares a specific action to be contrary to the German constitutional identity or demands the development of a fundamental rights protection, it makes the CJEU a take-it-orleave it proposition. If the CJEU wants to deviate, it comes into an open conflict with the Federal Constitutional Court. Such take-it-or-leave-it propositions give an enormous bargaining power to the actors who make them. ${ }^{55}$ This bargaining power is all the greater if the benefits of continued cooperation and thus the costs of rejection are high. This is the case, in particular, for the analyzed inter-court relationship where both courts have long-term incentives to avoid an open conflict over making short-term gains.

The bargaining position is reversed in the ultra vires scenario. While the Constitutional Court has the possibility to voice its preferences when making the preliminary reference request, it is the Court of Justice that ultimately makes a take-it-or-leave-it proposition. It is consistent with the procedural setting of the preliminary reference procedure that the Court of Justice is not bound by the interpretation of the court making the reference. However, if the referring court wants to deviate from the decision of the CJEU, it has to accept an open conflict with the latter. This is what the Federal Constitutional Court had to experience when making the OMT reference to the Court

\footnotetext{
BundesverfassungSGERICHTS [BVERFGE] 155, 232-33; Bundesverfassungsgericht [BVerfG] [Federal Constitutional Court] Dec. 19, 2017, 147 ENTSCHEIDUNGEN DES BundESVERFASSUNGSGERICHTS [BVERFGE] 364.

${ }^{49}$ Matthias Goldmann, Discretion, Not Rules: Postunitary Constitutional Pluralism in the Economic and Monetary Union, in Research Handbook on Legal Pluralism and EU Law 335, 349-50 (Gareth Davies \& Matej Avbelj eds., 2018).

${ }^{50}$ See Joseph H.H. Weiler, The Transformation of Europe, 100 Yale LaW Journal 2403, 2417-18, 2421 (1991).

${ }^{51}$ Maastricht, at 155.

${ }^{52}$ Lisbon Judgement, at 267.

${ }^{53}$ PSPP II.

${ }^{54}$ On constitutional identity arguments, see Theodore Konstantinides, Constitutional Identity as a Shield and a Sword: The European Legal Order within the Framework of National Constitutional Settlement, 13 CAMBR. YB. EUR. LEGAL STUD. 195 (2012); Theodore Konstantinides, Dealing with Parallel Universes: Antinomies of Sovereignty and the Protection of National Identity in European Judicial Discourse, 34 Yв. Eur. L. 127 (2015).

${ }^{55}$ Emanuel Towfigh \& Niels Petersen, Public and Social Choice Theory, in ECONOMIC Methods for LAwYERS 121, 134 (Emanuel Towfigh \& Niels Petersen eds., 2015).
} 
of Justice. ${ }^{56}$ While Karlsruhe framed its decision in the second OMT decision as if the Court of Justice had alleviated most of the concerns, ${ }^{57}$ it was clear that the Constitutional Court had failed to achieve its intended goals.

Therefore, it came as a great surprise to many observers when the Constitutional Court initiated a preliminary reference request regarding the PSPP program. ${ }^{58}$ When the Court of Justice turned down the second senate for a second time in Weiss, ${ }^{59}$ the Justices in Karlsruhe wanted to avoid the appearance of a second, readily foreseeable defeat. Wounded pride and vanity presumably played a major role. ${ }^{60}$ Consequently, they reprehended the Court of Justice for its "methodologically untenable", "simply not comprehensible" and "objectively arbitrary" reasoning. ${ }^{61}$ Nevertheless, they intended to minimize the scale of the escalation. They ultimately framed the reasoning as a procedural one, addressing the justification and not primarily the substance of the ECB decision. ${ }^{62}$ Furthermore, they gave the ECB a three-month window to remedy the defective justification of its policy. In the eyes of the second senate, this strategy could serve a double purpose: Giving a powerful rebuke to the CJEU, and turning the table on the ECB by extending a take-it-or-leave-it proposition to the latter. Nevertheless, the Court made a dangerous gambit that might well backfire.

\section{The Way Ahead}

On April 3, 2014, the Frankfurter Allgemeine Zeitung, one of the leading German daily newspapers, published a small note. ${ }^{63}$ It reported from a meeting of the German Federal Minister of the Interior with a few selected public law professors at an Italian restaurant in Berlin. The topic of the discussion: the reform of the German Federal Constitutional Court. In the years that have passed since this meeting, no serious proposals for a reform of the Court have emerged. Nor has the topic been openly discussed in political circles. Instead, the very purpose of the meeting was arguably to leak the information about it to the press. The reason was a couple of controversial decisions concerning European integration that the Constitutional Court had taken in the first quarter of 2014. The first of these decisions was the first OMT decision. ${ }^{64}$ In a second decision, the Court had struck down a 3\%-minimum-vote threshold for elections to the European Parliament. ${ }^{65}$ Both decisions arguably ran counter to the interests of the political elites. The dinner meeting in Berlin, therefore, was an allusion to Roosevelt's court-packing plan and a signal to Karlsruhe not to go too far.

Was the PSPP decision a step too far? There are several scenarios how the consequences of the decision might play out. The ECB could de-escalate the situation in the short-term by providing the

\footnotetext{
${ }^{56}$ Bundesverfassungsgericht [BVerfG] [Federal Constitutional Court] Jan. 14, 2014, 134 ENTSCHEIDUNGEN DES BUNDESVERFASSUNGSGERICHTS [BVERFGE] 366 [hereinafter OMT I].

${ }^{57}$ Bundesverfassungsgericht [BVerfG] [Federal Constitutional Court] June 21, 2016, 142 ENTSCHEIDUNGEN DES BundesverfassungsGerichts [BVERFGE] 123 [hereinafter OMT II].

${ }^{58}$ Bundesverfassungsgericht [BVerfG] [Federal Constitutional Court] July 18, 2017, 146 ENTSCHEIDUNGEN DES BundeSVERFASSUNGSGERICHTS [BVERFGE] 216 [hereinafter PSPP I].

${ }^{59}$ Case C-493/17, Weiss, ECLI:EU:C:2018:1000, Judgement of Dec. 11, 2018.

${ }^{60}$ Franz C. Mayer, Auf dem Weg zum Richterfaustrecht? - Zum PSPP-Urteil des BVerfG, https://verfassungsblog.de/aufdem-weg-zum-richterfaustrecht/. This is also suggested by the title of the article reporting on the case in the Economist: Seeing red: Germany's highest court takes issue with European Central Bank - Its decision imperils the entire legal order, The ECONOMIST, May 7, 2020, https://www.economist.com/europe/2020/05/07/germanys-highest-court-takes-issue-withthe-european-central-bank.

${ }^{61}$ PSPP II, at 117-18.

${ }^{62} \mathrm{Id}$., at $176-77$.

${ }^{63}$ Reinhard Müller, Berliner Gedankenspiele zur dritten Gewalt, FrankfurTer AllgemeIne ZeITUNG, April 3, 2014, https:// www.faz.net/-gpg-7olkl.

${ }^{64} \mathrm{OMT} I$, at 366.

${ }^{65}$ Bundesverfassungsgericht [BVerfG] [Federal Constitutional Court] Dec. 18, 2013, 135 ENTSCHEIDUNGEN DES BUNDESVERFASSUNGSGERICHTS [BVERFGE] 259 [hereinafter European Elections].
} 
cost-benefit analysis that the German Constitutional Court requested. While the ECB is unlikely to react to demands of member state institutions, the European parliament or the Council could pose a query to the ECB and ask for a proportionality assessment. ${ }^{66}$ Nevertheless, while providing short-term relief, it may have negative repercussions in the long run. The German Constitutional Court could feel emboldened to have an even more active role in interfering with ECB policy. This would not only create considerable uncertainty, ${ }^{67}$ but also undermine the ECB's political independence on which the German government insisted in the negotiations about its establishment.

If the ECB fails to provide an adequate cost-benefit assessment, the German Bundesbank becomes a central actor. The Bundesbank would have to comply with two competing, irreconcilable legal obligations. ${ }^{68}$ EU law would require it to continue purchasing bonds in the context of the PSPP program, while German constitutional law would oblige it to stop these purchases. The president of the Bundesbank, Jens Weidmann, is a well-known critic of the ECB's bond-buying programs. Nevertheless, he might also see the institutional danger that the Constitutional Court's challenge poses to the independence of the ECB and ultimately of the Bundesbank itself. ${ }^{69}$ It is not entirely clear how the Bundesbank will resolve this dilemma. In the short-term, the ECB could help the Bundesbank by temporarily superseding the PSPP program with the Pandemic Emergency Purchase Program (PEPP). The latter is a reaction to the economic troubles caused by COVID-19 and not covered by the legal effect of the German Constitutional Court's decision. However, this would again only be a short-term fix as the next constitutional complaint challenging the ECB policy would loom almost certainly. ${ }^{70}$

The court's decision does not only endanger the future role of the ECB. It has also severely damaged the authority of the CJEU. Even before the PSPP decision, courts of other member states had sometimes already taken a page out of Karlsruhe's playbook to defy the CJEU. ${ }^{71}$ This tendency will only be strengthened now that the EU's most powerful constitutional court has set an example of denying authority to a ruling of the Court of Justice. The most immediate danger probably comes from Hungary and Poland, where both governments have already welcomed the ruling. ${ }^{72}$ But it is also unclear what shape the relationship between the German Constitutional Court and the CJEU will take going forward. The second senate may be tempted to activate the ultra vires instrument also on other occasions. ${ }^{73}$ However, this may not have the intended effect of forcing the Court of Justice to give in to German pressure. Instead, it is more likely to lead to a breakdown of the cooperation that has so far characterized the relationship between both courts.

In the long run, the political reaction to the PSPP decision will be decisive. If the German government perceives the decisions of the Constitutional Court as a serious danger to

\footnotetext{
${ }^{66}$ See Daniel Sarmiento \& Joseph H.H. Weiler, The EU Judiciary after Weiss, https://eulawlive.com/op-ed-the-eujudiciary-after-weiss-proposing-a-new-mixed-chamber-of-the-court-of-justice-by-daniel-sarmiento-and-j-h-h-weiler/; Konrad Schuller, Deutschland und das Dilemma mit der EZB, Frankfurter Allgemeine Zeitung, June 7, 2020, https://www. faz.net/-gpg-a05t1 (referring to a proposal of the German MEP Sven Simon).

${ }^{67}$ Seeing red, supra note 50.

${ }^{68}$ András Jakab \& Pál Sonnevend, The Bundesbank is under a legal obligation to ignore the PSPP Judgment of the Bundesverfassungsgericht, https://verfassungsblog.de/the-bundesbank-is-under-a-legal-obligation-to-ignore-the-pspp-judgment -of-the-bundesverfassungsgericht/.

${ }^{69}$ See Hellwig, Eigentor der Bundesbank, supra note 41.

${ }^{70}$ The Court even extended an implicit invitation to bring a challenge to the PEPP program to Karlsruhe in its discussion of Art. 123 TFEU, see Miguel Poiares Maduro, Some Preliminary Remarks on the PSPP Decision of the German Constitutional Court, https://verfassungsblog.de/some-preliminary-remarks-on-the-pspp-decision-of-the-german-constitutional-court/.

${ }^{71}$ See Czech Constitutional Court, 31 January 2012, Pl. ÚS 5/12; Supreme Court of Denmark, 6 Dec. 2016, Case no. 15/2014, Dansk Industri (DI) acting for Ajos A/S vs. The estate left by A. (both declaring judgments of the Court of Justice to be ultra vires).

${ }^{72}$ Sam Fleming, James Shotter \& Valerie Hopkins, Eastern European states sense opportunity in German court ruling, FinANCiAL Times, May 10, 2020, https://www.ft.com/content/45ae02ab-56d0-486e-bea5-53ba667198dc.

${ }^{73}$ Mayer, supra note 49.
} 
European integration, voices for an institutional "reform", curtailing the independence of the Federal Constitutional Court, could grow louder. The German Constitutional Court could then face similar pressure as the U.S. Supreme Court at the end of the Lochner era. The German legislature could, for example, limit the competences of the Constitutional Court. ${ }^{74}$ The political riposte could also be more subtle: Two influential judges involved in the PSPP decision have either already left the court or are about to retire soon. President Andreas Voßkuhle has been replaced by Justice Astrid Wallrabenstein, who was nominated by the Green party. Furthermore, the rapporteur of the PSPP decision, Justice Peter Michael Huber, is due to retire from the Court in 2022. When searching for a successor, the political actors could well make a greater than usual effort to vet the potential candidates' stance on European integration issues.

But the German government also disposes of another option that Franklin D. Roosevelt did not have when he defended his "New Deal" program against the Lochner jurisprudence. Arguably, the ECB's quantitative easing policy was prompted by political inaction. There is some evidence that, in the long run, monetary unions face pressure either to dissolve or to take further steps towards integration. ${ }^{75}$ The ECB thus gave politics time to postpone the decision on the future of the monetary union. Uncertainty about the future ability of the ECB to provide this support might force politics to act more decisively. ${ }^{76}$ It may, therefore, not be a coincidence that the Macron-Merkel agreement on a 500 billion EUR pandemic recovery fund that would be guaranteed by all member states collectively through the $\mathrm{EU}^{77}$ came not even two weeks after the PSPP decision. If the latter indeed leads to an increasing communitarization of debt in the long run, this would, ironically, be exactly the opposite of what the applicants in the PSPP case had intended.

This range of different potential scenarios shows that it is difficult to predict the full consequences of the PSPP decision. This is even true for the Federal Constitutional Court itself. When the dust settles, Karlsruhe may well emerge stronger than ever, having dealt a significant blow to the authority of the CJEU and the independence of the ECB. More likely, the episode will only know losers, and the Court may have seriously weakened its own institutional position and independence.

\footnotetext{
${ }^{74} I d$.

${ }^{75}$ See Theresia Theurl, EINe gemeinsame Währung FÜr Europa (1992).

${ }^{76}$ Seeing red, supra note 50 .

${ }^{77}$ See Steven Erlanger, Merkel, Breaking German 'Taboo', Backs Shared E.U. Debt to Tackle Virus, N.Y. TimEs, May 18, 2020, https://nyti.ms/3e1eLgC.
}

Cite this article: Petersen N (2020). Karlsruhe's Lochner Moment? A Rational Choice Perspective on the German Federal Constitutional Court's Relationship to the CJEU After the PSPP Decision. German Law Journal 21, 995-1005. https:// doi.org/10.1017/glj.2020.54 